\title{
SIX YEARS OF SNOW-FENCE TESTING IN FRANCE
}

\author{
by
}

\author{
G. Brugnot
}

(Division Nivologie, CEMAGREF, BP 76, 38402 Saint-Martin-d'Hères Cédex, France)

\section{ABSTRACT}

Drifting snow creates problems which have practical effects in France in two situations. The first situation is when the result of wind action on snow is to cause accumulation of this snow on mountains, leeward of crests, and consequently to create the potential hazard of avalanche. The second is when the result is to pile up snow in flat regions wherever there are obstacles such as road cuttings and vegetation. This paper focuses on the second type of problem, which affects large areas of central and north-eastern France. We explain how we have chosen our test site, which initial experiments we have conducted in order to assess the general geometrical features which a snow fence must possess in order to function most effectively in collecting snow, and how subsequently we have assessed the properties and costs of different fencing systems.

\section{THE BESSE EN CHANDESSE TEST SITE}

In France most drifting snow problems occur in the region known as Massif Central. The characteristics of this region are its Paleozoic geology and its total area of $100000 \mathrm{~km}^{2}$, which includes large flat elevated plains at $800-1200 \mathrm{~m}$ a.s.l. surrounded by ancient volcanoes rising to 1900 m a.s.l. The most striking features of the regional climate are westerly winds and frequent precipitation due to the influence of the Atlantic Ocean. In winter as a result we have drifting periods of several days' duration and this causes considerable problems for road traffic. Economically the region remains rather traditional, with local tourism and agriculture as the main economic features, which explains why the communities are not very rich and why technical choices must therefore exclude any suggestion of luxury.

The Besse en Chandesse test site was chosen for its representative nature with respect to the above mentioned characteristics. Its elevation is $1200 \mathrm{~m}$ a.s.l., and the test site is a flat field open to wind from all directions and experiencing conditions which are representative of the most severe of possible road conditions in the Massif Central.

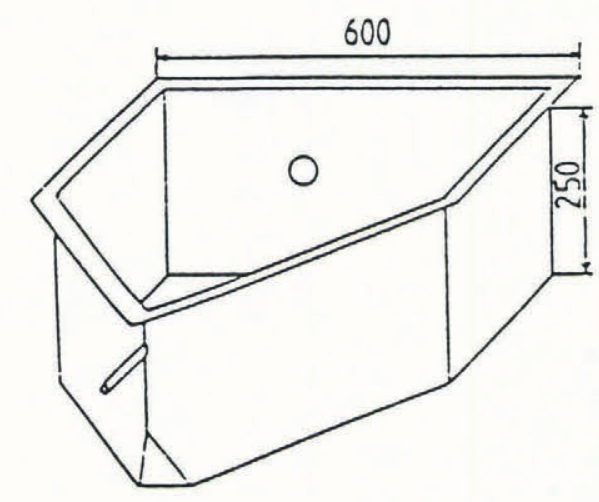

Fig. 1. Snow boxes (perspective view). NB: front view shows lid removed.

\section{OUTLINE OF THE STUDY}

In the first year of the study, 1982, we decided to place seven different kinds of snow fences in position to test their effectiveness and its dependence on their geometric characteristics. The original idea was to provide the Road Service with the data necessary for development of guidelines for designers of roads in mountain districts. The results amassed in the first years allowed us to determine the optimum snow fence geometry for local conditions. Subsequently we decided to test the mechanical and economical properties of different types of snow fence. In order to analyze and compare snow-fence performance it was necessary also to collect data about meteorology and snow conditions.

\section{SNOW AND METEOROLOGY MEASUREMENTS}

\section{Meteorological measurements}

Precipitation, or water equivalent of snowfall, was measured daily and temperature twice a day in order to obtain their maximum and minimum values. Wind velocity and direction were measured continuously, although the greatest problems with our experiments stemmed from the difficulty in measuring wind velocity and direction precisely. Blowing and drifting snow caused the anemometer to be blocked by snow and frost, sometimes making the velocity readings spurious and likely to be an underestimate of actual values.

\section{Snow-accumulation measurement}

The basic measurement made to assess the efficiency of snow fences was the measurement of the average volume of snow collected by means of snow poles. This measurement was made after every snow storm, with a maximum interval of 15 days, as were snow density measurements. We had 15 snow poles for each snow fence model, one at the snow fence, 9 leeward (east) and 5 windward (west).

\section{Snow collectors}

Snow collectors were tested during the winter of 1987-88. Fibre glass boxes and rackets were used. The boxes (Fig. 1) were stream-lined boxes with $10 \mathrm{~mm}^{2}$ entry cross-section, whereas the rackets (Fig. 2) were similar to those used by Mellor (1965). We had three profiles sites, one $50 \mathrm{~m}$ to windward of the snow-fence row and two $50 \mathrm{~m}$ down-wind of this row. Each profile site had four boxes, with their entry holes placed at $0.25,0.50,0.75$, and $1.0 \mathrm{~m}$ above the ground. It also had three rackets placed at $1.5,2.0$, and $2.50 \mathrm{~m}$ above ground level.

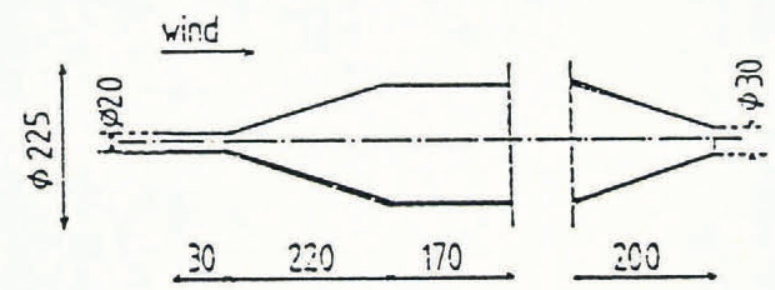

Fig. 2. Snow rackets, 


\section{SNOW AND METEOROLOGY RESULTS}

The meteorological data, along with snow-accumulation measurements, are presented in yearly charts which help in the analysis of snow accumulation periods and in the comparison of snow-fence performances (Centre d'Étude du Machinisme Agricole du Génie Rural, des Eaux et des Forêts, unpublished a, b, c, d, e.).

\section{Meteorological contrasts}

If we compare the different test winters from a meteorological point of view, we notice the sharp contrast which appears in Table $\mathrm{I}$.

\section{TABLE I. GENERAL METEROLOGICAL DATA}

Winter

$1982-83$

1983-84

$1984-85$

$1985-86$

1986-87

$1987-88$

Wood $=$ horizontal slats $/$ half rounds; $D=150 \mathrm{~mm}$, spaced $150 \mathrm{~mm}$ apart; height of panel $=2.35 / 2.50 \mathrm{~m}$; bottom gap = $0.60-0.75 \mathrm{~m}$; porosity $=50 \%$. Chestnut lattices and horizontal slats fences are classical types.

\section{Collectors}

Since the necessary collectors were not ready for use until the end of February the results obtained through their use are limited and difficult to analyse. The qualitative results we were able to obtain showed marked discrepancies between the volumes of snow collected by the boxes and by the rackets; the very sharp decrease in collected snow volume from the top box and the lower racket are at present impossible for us to explain completely. It appears that some of the snow initially collected by the rackets was lost by the time that collected volumes were noted, probably due to the fact that melting snow seeped out of the rackets. The unexpectedly high value for snow mass collected in these boxes has not been accounted for; from the results of the windward profile we get a total mass flux of about 30 tonnes for a $15 \mathrm{~d}$ period, which is approximately $20 \mathrm{~g} \mathrm{~m}^{-1} \mathrm{~s}^{-1}$ as an averaged value.

\section{SNOW-FENCE RESULTS}

\section{Different kinds of snow fence tested}

By using units $25 \mathrm{~m}$ long and with seven units in the same row, the total length of each system constructed was $175 \mathrm{~m}$. Chestnut snow fences were placed on each side of the system to eliminate border effects. It was not possible to find stretches of more than $200 \mathrm{~m}$ of homogeneous terrain on which snow fences could be sited. Tables II and III describe these models, all fences in Table III have a $300 \mathrm{~mm}$ gap at their base.

TABLE II. SNOW FENCES TESTED FROM 1982 TO 1988

\begin{tabular}{|c|c|c|c|c|c|c|}
\hline Vinter & $1982-83$ & $1983-84$ & $1984-85$ & $1985-86$ & $1986-87$ & $1987-88$ \\
\hline \multicolumn{7}{|l|}{ North } \\
\hline 1 & Horizonta & slats $15 \mathrm{~cm}$, & $H=1.65 \mathrm{~m}$ & $+0.30-0.60 \mathrm{~m}$ & & \\
\hline 2 & Horizonta & slats $15 \mathrm{~cm}$, & $H=1.65 \mathrm{~m}$ & $0.30 \mathrm{~m}$ & Synth. 4 & Synth. 4 \\
\hline 3 & Chestnut & lattices $/ H=$ & $1.50 m+0.3$ & & Synth. 5 & Synth. 5 \\
\hline 4 & Chestnut & lattices $/ H=$ & 2.00 & Synth. 4 & Wood & Wood \\
\hline 5 & Synth. 1 & Synth. 2 & Synth. 2 & Synth. 2 & Synth. 2 & Synth. 6 \\
\hline 6 & Synth. 2 & Synth. 3 & Chestn & $t$ lattices & Synth. 6 & Synth. 7 \\
\hline 7 & Self orien & ting fences $/ F$ & $I=1.50 \mathrm{~m}+$ & $0.30-0.60 \mathrm{~m}$ & Synth. 7 & Synth. 2 \\
\hline
\end{tabular}

TABLE III. SYNTHETIC SNOW-FENCE CHARACTERISTICS

$\begin{array}{ccrc}\text { Type } & \begin{array}{c}\text { Panel height } \\ (\mathrm{m})\end{array} & \begin{array}{c}\text { Opening size } \\ (\mathrm{mm})\end{array} & \begin{array}{c}\text { Porosity } \\ (\%)\end{array} \\ 1 & 1.20 & 100 \times 45 & \\ 2 & 1.85 & 100 \times 45 & 40 \\ 3 & 1.50 & 10 \times 5 & 50 \\ 4 & 1.50 & 78 \times 95 & 55 \\ 5 & 1.50 & 40 \times 80 & 58 \\ 6 & 2.20 & 115 \times 70 & 50 \\ 7 & 1.00 & 25 \times 60 & 46\end{array}$

Test results

All results from the 6 year test programme are contained in internal reports (Centre d'Étude du Machinisme Agricole du Génie Rural, des Eaux et des Forêts, unpublished a, b, c, d, e). Here we give only some examples of the data and the general conclusions reached by their interpretation. As an example, we provide the results of the maximum snow accumulation for the year of highest precipitation, 1985-86 (Table IV).

From these results we can deduce dimensionless quantities for snowdrifts created at saturated fences (Table $\mathrm{V})$. We do this by separately dividing the volume of snow collected by $\mathrm{H}^{2}$, the snowdrift length and the distance of

TABLE IV. SATURATION VALUES FOR TESTED SNOW FENCES (APRIL 1986)

\begin{tabular}{|c|c|c|c|c|c|}
\hline Type of fence & Che & stnut & Horizontal slats & Synthetic 2 & Self orienting \\
\hline Snow vol. & $1.50+0.30 \mathrm{~m}$ & $2.00+0.30 \mathrm{~m}$ & $1.65+0.30 \mathrm{~m}$ & & \\
\hline$A\left(\mathrm{~m}^{3} / \mathrm{m}\right)$ & 54.1 & 66.9 & 74.2 & 53.2 & 50.5 \\
\hline
\end{tabular}

TABLE V. DIMENSIONLESS CHARACTERISTICS OF SNOWDRIFTS AT SATURATION

Ratios:

Horizontal slats

Chestnut fences

Synthetic fence
Total height

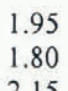

1.80

2.15
Volume

19.5

16.7

11.5

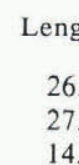

Position of max.

7.7

8.0

7.0

Note: To assess snowdrift length we considered as the leeward extremity the point where the snow was $0.30 \mathrm{~m}$ deep. 
Winter

$1982-83$

Fence 1 Fence 2

Total height $H(\mathrm{~m})$

Volume ratio

Bottom gap $(\mathrm{mm})$

$\begin{array}{rr}1.8 & 2.0 \\ 50.7 & 41.8 \\ 15.6 & 10.5 \\ 300 & 0\end{array}$

Snow collected $A\left(\mathrm{~m}^{3} / \mathrm{m}\right)$

the snow-fence point with maximum snow depth, by $H$, the total snow-fence height. The maximum snow-depth value obtained for drifted snow is $10 \%$ to $20 \%$ higher than $H$, the snow-fence height.

From these results we have deduced typical saturation values for a project with $50 \%$ porosity snow fences. These are

$$
A / H^{2}=20 ; \quad L / H=25 .
$$

\section{Importance of different snow-fence characteristics}

As bottom gap is a very important parameter, we decided to illustrate it by making a comparison between two kinds of chestnut fence, one of which was $1.50 \mathrm{~m}$ high with $300 \mathrm{~mm}$ bottom gap. Table VI demonstrates how bottom gap effects more than offset height effects. It clearly shows that with a one-third increase in surface area, the snow fence without a gap at the base collects, in the best case, only 5\% more snow than the fence with the $300 \mathrm{~mm}$ bottom gap. One technological problem is that there are difficulties in building chestnut fences with a gap at the bottom because they have a tendency to collapse.

In order to estimate the importance of having a gap at the bottom of a fence we conducted a test in which the bottom two slats of a horizontal slat snow fence were removed and then buried in snow to a depth of about $800 \mathrm{~mm} .15$ days later, on 15 February 1985, the snow fence was entirely scoured, with a snow depth of zero at ground level (Fig. 3).

Size of opening in fences is a factor which we have considered. We encountered considerable problems with synthetic snow fences. The first model proposed by the companies manufacturing this product had the correct average porosity but only very small openings, which therefore became clogged by drifting snow; this helps to explain the inconsistent results for synthetic snow fences shown in Table V. From our own observations, and after subsequent adjustments in the opening mesh size, we formulated the guideline that the optimum characteristic dimension for fence-lattice openings would be about $100 \mathrm{~mm}$. Making the appropriate changes improved considerably the consistency with other data of the results obtained in the 1986-87 season.

\section{TECHNOLOGICAL AND ECONOMIC DATA}

The best way of comparing snow-fence models is to calculate the efficiency: cost ratio, which we get by dividing the cost of a fence model by the maximum volume

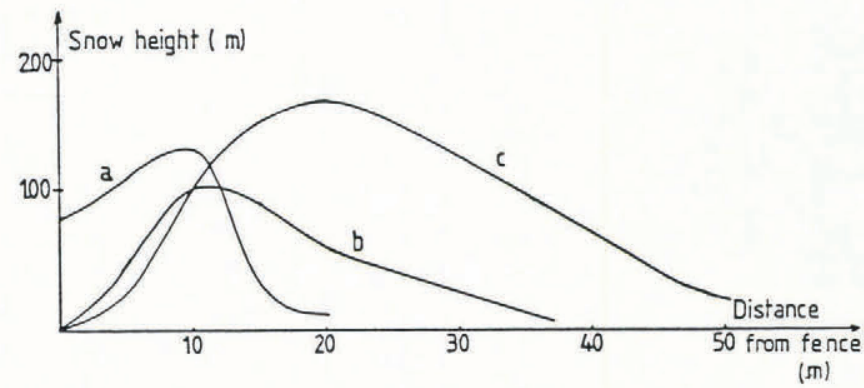

Fig. 3. Snow profile (a) before and (b) after removal of bottom slats. $\mathrm{c}$ is saturation profile.
$1983-84$

$1984-85$

\begin{tabular}{|c|c|c|c|}
\hline Fence & Fence 2 & Fence 1 & Fence \\
\hline 1.8 & 2.0 & 1.8 & 2.0 \\
\hline 75.4 & 80.1 & 58.0 & 59.5 \\
\hline 23.3 & 20.1 & 17.9 & 14.9 \\
\hline 300 & 0 & 300 & 0 \\
\hline
\end{tabular}

of snow it can collect. This index has the unit of French francs $(\mathrm{Fr}) / \mathrm{m}^{3}$, and takes into account the physical effects of a snow fence as well as its cost. In addition to the purchase price, the cost includes the cost of maintenance and where appropriate the annual cost of removing and re-setting the fence again. The agricultural economy in most places where snow fences are used requires they be removed every year in mid-spring. According to the most recent available results, for winter 1986-87, the cost: efficiency ratio ranges from $0.4 \mathrm{Fr} / \mathrm{m}^{3}$ to $0.7 \mathrm{Fr} / \mathrm{m}^{3}$ for synthetic fences if we consider fences which must be removed every year; the purchase cost represents roughly half of the cost. This compares with $0.2 \mathrm{Fr} / \mathrm{m}^{3}$ to $0.3 \mathrm{Fr} / \mathrm{m}^{3}$ for chestnut fences, and fixed fences have values ranging from $0.3 \mathrm{Fr} / \mathrm{m}^{3}$ to $0.6 \mathrm{Fr} / \mathrm{m}^{3}$.

\section{DEVELOPMENTS IN SNOW-FENCE TECHNOLOGY IN FRANCE}

The reasons why we chose the models actually tested in Besse en Chandesse are related to the survey conducted in 1987 by the Centre d'Etudes Techniques de l'Equipement (CETE) of the Department of Transport. The main aim of our survey was to reach a better knowledge of the snow fences currently being used in France and of the models which the regions plan to purchase in the near future. The Appendix to this survey reflects the eagerness of users to replace the classic chestnut latticed fences by synthetic fences, which are easy to set up and remove.

\section{CONCLUSION}

Although scientists do not agree about the basic physical processes of snow transport, they recognize that snow fences are very efficient in flat countries in preventing snowdrifts from blocking roads. Having determined which kinds of snow fences have the greatest efficiency in given conditions in central France we plan to continue making measurements in order to improve our knowledge of the mechanisms by which snow fences collect snow.

\section{ACKNOWLEDGEMENTS}

We wish to express our gratitude to the Ministry of Transport (SETRA) in Paris, as well as to its local branches (Centre d'Etudes Techniques de l'Equipement) in Lyon, Clermont Ferrand and Besse for their financial and practical aid in this study.

\section{REFERENCES}

Centre d'Étude du Machinisme Agricole du Génie Rural, des Eaux et des Forêts. Unpublished a. Essais comparatifs de barrières á neige, campagne d'observation 1982-1983. Internal report.

Centre d'Étude du Machinisme Agricole du Génie Rural, des Eaux et des Forêts. Unpublished b. Essais comparatifs de barrières á neige, campagne d'observation 1983-1984. Internal report.

Centre d'Étude du Machinisme Agricole du Génie Rural, des Eaux et des Forêts. Unpublished c. Essais comparatifs de barrières á neige, campagne d'observation 1984-1985. Internal report. 
Centre d'Étude du Machinisme Agricole du Génie Rural, des Eaux et des Forêts. Unpublished d. Essais comparatifs de barrières á neige, campagne d'observation 1985-1986. Internal report.

Centre d'Étude du Machinisme Agricole du Génie Rural, des Eaux et des Forêts. Unpublished e. Essais comparatifs de barrières á neige, campagne d'observation 1986-1987. Internal report.

Mellor, M. 1965. Blowing snow. CRREL Monogr. III, A3c.

\section{APPENDIX}

DATA FROM 1987 SURVEY OF SNOW FENCES IN FRANCE

(Lengths of snow fences in $\mathrm{km}$ in all sets of data)

1. Elevation

$<500 \mathrm{~m}$

500 to $1000 \mathrm{~m}$

$>1000 \mathrm{~m}$

Interprovincial roads Provincial roads

2. Types

Interprovincial roads

Provincial roads

Chestnut lattices

Wooden slats

16.9

0.7

311.5

Synthetic fabric
3. Height

$<1.50 \mathrm{~m}$

$>1.50 \mathrm{~m}$

Not known

4. Bottom gap

Bottom gap

No bottom gap
All categories of road

147.4

40.4

All categories of road

329.8

5. Planned installations ( $\mathrm{km}$ of snow fences still to be built; data obtained from replies of local branches of the Road Administration to queries)

5.1 Where?

Interprovincial roads 69.1

Provincial roads $\quad 481.0$

5.2 What type?

Chestnut lattices 156.0

Wooden slats $\quad 16.9$

Synthetic fabric $\quad 377.2$ 